\title{
Impact of Macroeconomic Variables on Stock Markets: Evidence from Emerging Markets
}

\author{
Mahmoud Ramadan Barakat ${ }^{1}$, Sara H. Elgazzar ${ }^{1} \&$ Khaled M. Hanafy ${ }^{1}$ \\ ${ }^{1}$ Logistics of international trade department, College of International Transport and Logistics, Arab academy for \\ science and technology and maritime transport, Alexandria, Egypt \\ Correspondence: Mahmoud Ramadan Barakat, Logistics of international trade department, College of \\ International Transport and Logistics, Arab academy for science and technology and maritime transport, \\ Alexandria, Egypt. Tel: 201-119-933-344. E-mail: mahmoud.barakat@aast.edu
}

Received: November 11, 2015

Accepted: December 8, 2015 Online Published: December 25, 2015

doi:10.5539/ijef.v8n1p195

URL: http://dx.doi.org/10.5539/ijef.v8n1p195

\begin{abstract}
The key objective of this study is to shed light on the relationship between the stock market and macroeconomic factors in two emerging economies (Egypt and Tunisia) for the period from January 1998 to January 2014. Results indicated that there is a causal relationship in Egypt between market index and consumer price index (CPI), exchange rate, money supply, and interest rate. The same goes for Tunisia except for CPI, which had no causal relationship with the market index. Results also revealed that the four macroeconomic are co-integrated with the stock market in both countries.
\end{abstract}

Keywords: macroeconomic variables, developing economies, stock market, co-integration, Granger causality

\section{Introduction}

Stock is one of the most sensitive assets to economic condition. Any aggressive change in stock prices can have negative implications for an economy, which makes the causal relationship between macroeconomic variables and stock returns one of the most debated topics in finance in the past few decade (Ozbay, 2009).

The attention that the stock market attracted was not only limited to policy makers and researchers, rather the relationship between macroeconomic variables and stock market also attracted the attention of economists and financial investors because of three reasons. First, policy makers would be able to predict the full effect of current and upcoming policies and regulations. Second, investors can make more informed decision when they fully understand this relation and thus decrease their exposure to risk. Third, if the public are aware of the changes that might happen in the economy or the financial market, the shock factor will be reduced and the public will be able to take protective measures (Abu-Libdeh \& Harasheh, 2011). However, this attention was mainly focused on developed countries and only few researches investigated this relationship in developing countries (Ali, 2011). In a developed economy, the nature of the relationship between stock market and macroeconomic variables may differ from developing economies. Therefore, the aim of this study is to explore the nature of the relationship between four macroeconomic variables (Exchange Rates, Interest Rates, Money Supply and Inflation) and the stock market in two developing economies: Egypt and Tunisia. These four variables are the most reliable macroeconomic variables that can explain stock markets fluctuations (Graham \& Harvey, 2001; Kim, 2003; Rapach et al., 2005; Yau \& Nieh, 2006; Adrangi et al., 2011).

Countries under investigation (Egypt and Tunisia) were selected because of their similarities, being in the same region and facing the same conditions, and most importantly, both market indices started at the same time. Additionally, both countries had a revolution around the same time and they did not end up like Libya or Syria, they are still intact trying to rebuild their economies. In order to rebuild strong economies, both countries need a well functioning financial system, which is the milestone of a strong economy and which definitely includes stock market. This research will focus on the nature of the relationship between macroeconomic variables and the stock market. This will have a practical significance because a deeper understanding of the behavior of the stock market will allow firms to work more efficiently. By gaining knowledge about the nature of this relationship, governments can stabilize the stock market and the economy as a whole, which will attract more investors as well as firms and will help control bad economic situations. In addition, it will be the first step to facilitate the transition to a stronger economy. 
The rest of this paper is organized as follows; section two reviews papers examining the relationship between macroeconomic variables and stock market. Section three defines the research variables, methodology, hypothesis and research strategy. Section four presents results of the paper and finally section five concludes the research and gives recommendation for future work.

\section{Literature Review}

The usefulness and importance of stock market have been recognized by some developing countries as they improve the quality and efficiency of domestic financial system. What emphasizes the stock market importance and the attention it has attracted is the exposure of local markets to the international community, which makes a global capital market inevitable, a market that is associated with a flexible exchange rate system and globalization of financial markets. This has attracted the attention of many researchers to investigate the variables affecting stock markets (Aliyu, 2009).

The effect of some macroeconomic variables could vary from one market to another and from one period to another. This urged a more in depth investigation of the nature of the relationship between macroeconomic variables and stock markets in different economies, especially after major changes. Any changes that affect the economic conditions in general, such as removing restrictions in foreign investment, will definitely cause changes in the stock market and its relation to the economic factors. Reinvestigating the nature of the relationship between the stock market and the macroeconomic factors will be appropriate and essential for investors because the dynamics of this relationship have changed (Pramod-Kumar \& Puja, 2012).

In this regard, Bhunia (2012) argued that although there are theoretical and empirical studies that investigated the direction of causality between macroeconomic variables and stock market, the direction of the causality is not known yet in empirics as well as in theory. As some studies show empirical evidence proofing causality, other studies show no causal relationship. In addition, the direction of the causality changes from one economy to another.

The great impact of macroeconomic variables on the stock market, and the important role the stock market plays in the economy by affecting its major factors which in return affect the investment decisions makes any investor should be aware of the dynamic relationship between the stock market and macroeconomic variables so that he/she can manage his/her investments more efficiently (Osamwonyi \& Evbayiro-Osagie, 2012).

The performance of an economy can be measured by real GDP growth rate, rate of inflation, exchange rate, fiscal position, debt position and many other variables, which can also serve as the major determinants of economic growth. Since the stock market reflects the economic fundamentals, stock market prices should be employed as a leading indicator of future economic activity (Pal \& Mittal, 2011). Various studies found that changes in fundamentals of the economy greatly affect stock market indices (Ahmed, 2008). Stock prices and hence market index are considered to be one of the best indicators of changes in economic activities by empirical studies and economic theories. If an investor wants more return on his/her investments, he/she must focus mainly on the macroeconomic variables that affect the stock prices (Musílek, 1997).

Chen et al. (1986) stated and empirically presented how movement in macroeconomic variables affects future dividends and discount rate and therefore stock prices. When Smith (1990) studied the stock market behavior in the United States, he detected that it changes through the different phases of the economic cycle as it declines shortly before a recession begins and rises shortly before a recession ends. Atje and Jonanovic (1993) argued that stock market development, specifically trading volume, has a relationship with economic growth. Levine and Zervos (1998) and Singh (1997) showed evidence that there is a positive relationship between stock market development and long run economic growth.

Fama (1981) and Chen et al. (1986) tested the long term relationships between the changes in stock prices and macroeconomic variables in the United States. They argued that there is a long term relationship between macroeconomic variables and stock market. Fama (1981) stated that there is a strong positive correlation between common stock returns and real economic variables like capital expenditures, industrial production, real GNP, money supply, lagged inflation and interest rates. Chen et al. (1986) argued that the relevant economic variables that affect stock market are aggregate production, inflation, short-term interest rates, the maturity risk premium and default risk premium. Mukherjee and Naka (1995) found a significant relation between exchange rate, money supply, inflation and industrial production and stock prices.

Other researchers Ibrahim (2003), Chaudhuri and Smiles (2004), and Buyuksalvarci (2010) found a significant relation between stock market and real output, aggregate price level, money supply, exchange rate, real GDP, real private consumption, real money, real oil price, interest rate, production index, oil price and exchange rate. 
The preliminary analysis reveals that changes in money supply, interest rates, inflation and other macroeconomic variables have a relationship with stock markets. This relationship can be reversible; stock market can influence the economy as Smith (1990) stated, or the economy can influence the stock market as Amadi and Odubo (2002) showed in their study.

Tangitprom (2012) stated that although the studies examining the causal relation between stock market and macroeconomic variables conclude different results, most of these studies agreed that there are significant relationships between macroeconomic variables and stock markets. These different results are due to different market regulations, investors, country location and other factors. Although macroeconomic variables are common, it is hard to generalize the results because the same variables have different impact in different economies (El-Nader \& Alraimony, 2012). Bhunia (2012) and Pramod Kumar and Puja (2012) added that different periods will also result in different outcomes.

The review indicated that studies investigated the relationship between macroeconomic variables and stock market can be divided into three groups. Some researchers found that there is a significant relationship between macroeconomic variables and stock market (Bilson et al., 2001; Hondroyiannis \& Papapetrou, 2001; Ibrahim \& Aziz, 2003; Tsoukalas, 2003; Maysami et al., 2004; Coleman \& Tettey, 2008; Horobet \& Dumitr, 2009; Buyuksalvarci, 2010; Geetha et al., 2011; Ali, 2011; Rafique et al., 2013; Lakshmi \& Tuwajri, 2014; Wongbangpo \& Sharma, 2002; Masuduzzaman, 2012; \& Ray, 2012). Other found no significant relationship between macroeconomic variables and stock market (Mohammad et al., 2009; Bhattacharya et al., 2001; Ali, 2011). While others found that some variables are significant and some are not significant (Kurihara, 2006; Pal \& Mittal, 2011; Singh et al., 2011; Ullah et al., 2014).

Table 1 summarizes the previous studies that reviewed the relationship between macroeconomic variables and stock market. The table illustrates studies according to the macroeconomic variables and countries under investigation.

Table 1. Impact of macroeconomic variables on stock market

\begin{tabular}{|c|c|c|}
\hline Author/s & Country & Macroeconomic variables \\
\hline $\begin{array}{l}\text { Hondroyiannis and } \\
\text { Papapetrou (2001) }\end{array}$ & Greece & $\begin{array}{l}\text { Real oil prices, interest rate, exchange rate and the } \\
\text { performance of foreign stock market }\end{array}$ \\
\hline Bilson et al. (2001) & $\begin{array}{l}\text { Argentina, Brazil, Chile, Colombia, Mexico, } \\
\text { Venezuela, India, Malaysia, Pakistan, } \\
\text { Philippines, Taiwan, Thailand, Greece, } \\
\text { Jordan, Nigeria and Zimbabwe }\end{array}$ & Goods prices, real activity and money supply \\
\hline Bhattacharya et al. (2001) & India & Exchange rate, foreign exchange rate and trade balance \\
\hline $\begin{array}{l}\text { Wongbangpo and Sharma } \\
\text { (2002) }\end{array}$ & $\begin{array}{l}\text { Indonesia, Malaysia, Philippines, Singapore, } \\
\text { and Thailand }\end{array}$ & $\begin{array}{l}\text { Stock price index, GNP, CPI, money supply, interest rate } \\
\text { and exchange rate }\end{array}$ \\
\hline Ibrahim and Aziz (2003) & Malaysia & $\begin{array}{l}\text { Industrial production, money supply, consumer price } \\
\text { index and exchange rate }\end{array}$ \\
\hline Tsoukalas (2003) & Cyprus & $\begin{array}{l}\text { Money supply, industrial production, exchange rates and } \\
\text { the consumer price index }\end{array}$ \\
\hline Maysami et al. (2004) & Singapore & $\begin{array}{l}\text { Interest rate, industrial production, money supply, } \\
\text { consumer price index and exchange rate }\end{array}$ \\
\hline Kurihara (2006) & Japan & $\begin{array}{l}\text { Interest rate, exchange rate and United States' stock } \\
\text { prices }\end{array}$ \\
\hline Coleman and Tettey (2008) & Ghana & Lending rates, inflation and stock market performance \\
\hline Horobet and Dumitr (2009) & Poland & $\begin{array}{l}\text { GDP, CPI real interest, money supply and real effective } \\
\text { exchange rate }\end{array}$ \\
\hline Mohammad et al. (2009) & Pakistan & $\begin{array}{l}\text { Industrial production, gross fixed capital formation, } \\
\text { foreign exchange reserve, exchange rate and board } \\
\text { money supply }\end{array}$ \\
\hline Buyuksalvarci (2010) & Turkey & $\begin{array}{l}\text { Money supply, interest rate, production index, oil price } \\
\text { and exchange rate. }\end{array}$ \\
\hline Pal and Mittal (2011) & India & Interest rate, inflation rate, exchange rate and GDP \\
\hline Singh et al. (2011) & Taiwan & $\begin{array}{l}\text { GDP, employment rate, exchange rate, inflation, money } \\
\text { supply, exchange rate, GDP and inflation }\end{array}$ \\
\hline
\end{tabular}




\begin{tabular}{|c|c|c|}
\hline Geetha et al. (2011) & Malaysia, US and China & $\begin{array}{l}\text { Expected inflation rate, unexpected inflation rate, } \\
\text { exchange rate, interest rate and GDP }\end{array}$ \\
\hline Ali (2011) & Bangladesh & $\begin{array}{l}\text { Inflation, foreign remittance and growth in market } \\
\text { capitalization }\end{array}$ \\
\hline Masuduzzaman (2012) & Germany, United Kingdom & $\begin{array}{l}\text { Inflation, money supply, industrial production and } \\
\text { exchange rate }\end{array}$ \\
\hline Ray (2012) & India & Foreign exchange reserve \\
\hline Rafique et al. (2013) & Pakistan & $\begin{array}{l}\text { CPI, discount rate, per capita income and saving to GDP } \\
\text { ratio }\end{array}$ \\
\hline Ullah et al. (2014) & Pakistan & Exchange rates, inflation and interest rate \\
\hline Lakshmi and Tuwajri (2014) & Saudi Arabia & $\begin{array}{l}\text { Consumer price index, industrial output, money supply, } \\
\text { oil prices and exchange rate }\end{array}$ \\
\hline
\end{tabular}

The previous discussion declared that most of studies focused on developed economy while there is lack of studies regarding emerging economies, especially in the Middle East and North Africa (MENA) region. This shows the gap that this paper sheds light on. The review also concluded that findings vary from one country to another, which emphasizes the importance of examining the relationship between macroeconomic variables and stock market in each country as the findings cannot be generalized.

In this paper, an applied research will be used as a strategy in order to investigate the relationship between macroeconomic variables and stock market, which will help investors take corrective action regarding their investment and hedge against the fluctuations in the stock market. The study will also help governments to predict the impact of their decision on the stock market, which will lead to a more stable stock market and a stable economic growth in general. In addition, it helps investors as well as the government to predict any changes in economic conditions due to fluctuations in the stock market. This will be achieved by analyzing the nature of the relationship between macroeconomic variables and stock market index in both Egypt and Tunisia. The next section will define the research variables and the research hypothesis upon which the research strategy and research method are developed.

\section{Methodology}

\subsection{Research Variables}

This research aims to identify the nature of the relationship between macroeconomic variables and the stock market. The variables under investigation are deposit rate as proxy for Interest rate, CPI as proxy for inflation, local currency per US dollar as proxy for exchange rate, M2 as proxy for money supply, and finally market index as proxy for the stock market. The research variables are discussed below in more details.

Market index: to help all those who are interested in the stock market either government officials, investors, or academics a stock market index was invented as a tool in order to be able to evaluate the decision of portfolio managers and investment advisors. An index is a collection of the major firms stock in the economy (Strong, 2005). According to Rafique et al. (2013), the stock market performance is measured through movement in the index. The fluctuation in the index is affected by macroeconomic, social, political, international variables and the firm's specific variables.

Interest rate: the pure rate of interest is defined by Reilly and Brown (2003) as the rate of exchange between future and current consumption. When people accepted to pay this difference when borrowing money and receiving it on their saving, this caused the emergence interest rate which the authors referred to as the pure time value of money. Moreover, if the investor expects an increase in prices (rise in inflation), he/she will demand a higher rate of return that is the pure time value of money plus expected inflation rate. Additionally, in an uncertain environment people will demand an interest rate that is greater than the pure time value of money plus the expected inflation rate to counterweigh the uncertainty.

Uddin and Alam (2007) used interest on deposit as a proxy for interest rate. They argued that theoretically interest rate has a negative relationship with stock prices. When the rates on deposits in the bank increase, people will redirect their money from the capital market to the banks and this will lead to a decrease in the demand of shares. Definitely, the opposite will happen if the deposit rate decreases. Additionally, when interest on deposit increases, lending rate also increases, which will have a negative impact on investment in the economy and hence the stock prices and vice versa.

Inflation: McConnell et al. (2012) defined inflation as an increase in the general price levels. When inflation 
occurs, purchasing power decreases as each unit of income can buy less goods and services. They argued that Consumer Price Index (CPI) is the main measure of inflation. Talla (2013) used consumer price index as a proxy for inflation. He argued that inflation can affect stock market either positively or negatively. He added that unexpected and expected inflation determines the direction of the relationship between stock market and inflation. When demand exceeds supply, firms tend to increase their prices. This would increase their earnings, which would lead to an increase in dividends paid resulting in an increase in demand for the firm's stock and eventually increasing its stocks value. That is in the case of expected inflation.

As for unexpected inflation, an increase in the general price levels leads to the increase in cost of living, which will force people to invest less and relocate their resources to consumption. When inflation increases, nominal interest rates also increase. This will reduce the present value of the income generated by firms as the discount rate used to determine the intrinsic values of stocks went up. This will force stock prices to decrease. Additionally, if the price elasticity of demand for the firm's product is high, a rise in inflation that leads to an increase in prices will cause a decline in a firm's sales and net income, and thus its stock price.

Exchange rate: Gunasekarage et al. (2004) and Adam and Tweneboah (2008) used national currency per United States dollar (USD) as a proxy for exchange rate. As exchange rate is the price of a currency in terms of another currency, it will affect net exports (Osamwonyi, 2003 cited in Osamwonyi \& Evbayiro-Osagie, 2012). Vejzagic and Zarafat (2013) found that changes in exchange rates would have an impact on the firm's competitiveness as it affects the price of foreign currency, leading to changes in the firm's profits and equity, which in return will lead to price adjustments in the stock market.

According to the portfolio adjustment approach, any inflow or outflow of foreign capital will be a result of a change in stock prices. That is, when stock prices increase, they will attract foreign capital and when prices decrease, they will be less appealing to foreign investors, which will lead to a reduction in corporate wealth and as a result a reduction in the country's wealth (Vejzagic \& Zarafat, 2013).

Money supply: Walter (1989) argued that monetary aggregates can be used to measure any nation's money stock. M1 is the most narrowly defined monetary aggregate; it is the sum of dollar amounts of currency, nonbank traveler's checks in circulation and checkable deposited. M2 is broader than M1 as it contains all the components of M1 in addition to overnight repurchase agreements, overnight Eurodollar deposits, general purpose and broker/dealer money market fund balances, money market deposit accounts, and savings and small time deposits. M3 is the broadest monetary aggregate; it is the sum of M2 and large time deposits, term repurchase agreements, term Eurodollar deposits, and balances in money market funds employed solely by institutional investors.

$\mathrm{He}$ also stated that in order to forecast the changes in economic activities, inflation and interest rates, analysts need to study the relationship between the monetary measures stated above and other macroeconomic variables, i.e. national income, employment, interest rates and the price level.

Reilly and Brown (2003) argued that in the short run disequilibrium in the supply and demand of capital might occur and it will change the ease or tightness of the capital market. A sudden change in the money supply among other variables might be the cause of this disequilibrium through affecting the nominal risk free rate. The authors mentioned that the disequilibrium will only hold in the short run and the market will return to equilibrium in the short run. A tightening in monetary policy, which means a decrease in the growth rate of money supply, will result in a decline of supply of capital and an increase in interest rates. Increase in interest rates will cause an increase in savings and a decrease in the demand for capital. Sequentially, at the end, these changes will push the market back to equilibrium.

Hamburger and Kochin (1972), Kraft and Kraft (1977) and Sirucek (2011) used M2 as a proxy of money supply and stated that there is a strong relation between money supply (M2) and stock prices. Table (2) illustrates the research variables and the proxy of each variable used in this study.

Table 2. The research variables and the proxy for each variable

\begin{tabular}{ll}
\hline Variables & Proxy \\
\hline Stock market & Market Index \\
Interest Rate & Interest on Deposit \\
Inflation & CPI \\
Exchange Rate & National Currency Per USD \\
Money Supply & M2 \\
\hline
\end{tabular}




\subsection{Hypothesis}

Eight testable hypotheses were derived to test the relationship between independent variables (interest rate, inflation, exchange rate and money supply) and dependent variable (stock market index).

H1: Interest rate does not affect stock market index in the long run.

$\mathrm{H} 2$ : There is no causal relationship between stock market index and interest rate.

H3: Inflation does not affect stock market index in the long run.

H4: There is no causal relationship between stock market index and inflation.

H5: Exchange rate does not affect stock market index in the long run.

H6: There is no causal relationship between stock market index and exchange rate.

H7: Money supply does not affect stock market index in the long run.

H8: There is no causal relationship between stock market index and money supply.

\subsection{Research Strategy}

A quantitative research approach using an empirical analysis will be conducted through statistical techniques to test the hypotheses of this study. The data that will be used in this study is secondary data published in official databases. Monthly data were selected from IMF (International Monetary Fund) database (Morley, 2009; El-Nader \& Alraimony, 2012) through the period January 1998 until January 2014 For Egypt and Tunisia. This specific period was selected since EGX 30, the Egyptian stock market index, and TUNINDEX, the Tunisian stock market index, started at 1-1-1998 and 31-12-1997, respectively. The market index will serve as an indicator for the stock market as for the macroeconomic variables nominal interest rates, inflation (consumer price index), nominal exchange rate and money supply will be used.

To reach the objective of the study various econometrics tests will be carried out, namely unit root test, Augmented Dicky Fuller (ADF) test proposed by Dicky and Fuller (1981), Johansen (1988), Vector Auto Regression (VAR) to select the optimal lag length, co-integration test, and Granger causality test.

To test the causal relationship of macroeconomic variables on stock market index, data must be co-integrated, which means they would not gradually move away from each other over time. When the long run equilibrium is proven, the test generates a long run equation with normalized co-integrating coefficients which can be used to determine the effect of the macroeconomic variables on the stock market index.

To select the appropriate co-integration test, the order of integration of each variable must be determined first by using ADF, which determines whether the data series is stationary (has no unit root) or not. If all the variables are stationary at first difference, this means that they are integrated of the same order.

After the long run equilibrium is proven through Johansen test, parewise Granger causality will be used to test if there is a short run causal relationship between the four macroeconomic variables and the stock market index. Granger causality means that one variable past can help predict another variable. For example, if it was established that variable $X$ is Granger cause variable $Y$, this means that the historical data of $X$ can be used to predict $Y$. This relation can be bidirectional which means $Y$ can also Granger cause $X$ (Stern, 2011). In other words, it determines whether the selected macroeconomic variables can be useful in forecasting the stock market index fluctuations and whether these macroeconomic variables are affected by the stock market index. Table (3) summarizes the tests that will be conducted along with their purpose.

Table 3. Statistical tests used for the analysis

\begin{tabular}{ll}
\hline Test/s & Purpose \\
\hline ADF & Test for unit root \\
VAR & Choosing lag length \\
Johansen test for co-integration & Co-integration test \\
Granger causality & Testing the causal relationship \\
Long run equation & Testing long run relationship \\
\hline
\end{tabular}




\section{Results and Analysis}

\subsection{ADF}

At this step, data are tested by using ADF to determine whether the data are stationary on level or at first difference. The null hypothesis for ADF test is:

$\mathrm{H}_{0}$ : the variable has a unit root

The ADF test statistics are given in Table 4. Results indicate that $\mathrm{H}_{0}$ will be rejected for all the variables, which indicates that there is no unit root problem in all the variables at $\mathrm{I}(1)$, and all the variables contain unit root in $\mathrm{I}(0)$.

For both Egypt and Tunisia, the data were found to be not stationary at level I(0) at $5 \%$ level of significance and when converted to first difference I(1), all variables are stationary at 5\% level of significance.

Table 4. The results of ADF test for both Egypt and Tunisia

\begin{tabular}{llcccc}
\hline & & \multicolumn{2}{c}{ Egypt } & \multicolumn{2}{c}{ Tunisia } \\
\cline { 3 - 5 } LogI & & At Level & First Difference & At Level & First Difference \\
\cline { 3 - 6 } LogIR & t-Statistic & -0.713548 & -11.41234 & -0.410077 & -12.97031 \\
& Prob & 0.8396 & 0.0000 & 0.9037 & 0.0000 \\
\multirow{2}{*}{ LogCPI } & t-Statistic & -1.562441 & -7.656887 & -2.515308 & -5.708008 \\
& Prob & 0.4998 & 0.0000 & 0.3205 & 0.0000 \\
\multirow{2}{*}{ LogER } & t-Statistic & -1.821945 & -8.762865 & 3.031639 & -9.883139 \\
& Prob & 0.6904 & 0.0000 & 1.0000 & 0.0000 \\
\multirow{2}{*}{ LogMS } & t-Statistic & -1.294295 & -11.18422 & -1.455769 & -12.94015 \\
& Prob & 0.6321 & 0.0000 & 0.5540 & 0.0000 \\
& t-Statistic & -1.850100 & -12.74234 & -2.333062 & -14.39459 \\
\hline
\end{tabular}

Note. Where I is stock market index, IR is interest rate, CPI is consumer price index, ER is exchange rate and MS is the money supply.

\subsection{Vector Auto Regressive (VAR)}

The second step is using VAR to determine the optimal lag length selection based LR test, Akaike Information Criterion (AIC), Final Prediction Error (FPE), Schwarz Criterion (SC), Hannan and Quinn Criterion (HQ) through VAR. Based on the results, the different lag length chosen for Egypt was 1 by SC and HQ and 2 by LR, FPE and AIC. As for Tunisia, lag length 1 was chosen by SC and HQ, lag length 2 was chosen by FPE and AIC. Finally, lag length 5 was chosen by LR.

Gutierrez et al. (2009) stated that AIC performs better than other criteria when selecting the model. In addition, it is the most accurate criteria for selecting the lag length for 100 and 200 observations. Since the observations used in this study are 193, the lag length 2 selected by AIC criterion for both Egypt and Tunisia will be adapted.

\subsection{Johansen Test}

After handling the varying lag length recommendations, Johansen test of co-integration through Unrestricted Co-integration Rank Test (Maximum Eigenvalue) (Lakshmi \& Tuwajri, 2014) for the lags chosen will be conducted to discover if there is long run equilibrium between the stock market index and the four macroeconomic variables.

Null hypothesis for Johansen co-integration test is:

$\mathrm{H}_{0}$ : there is no co-integration between the variables

For Egypt and Tunisia, the test suggests that null hypothesis is rejected at 5\% significance level which means there is at least one co-integration equation. This confirms that EGX 30 and TUNINDEX, the stock market indices, in Egypt and Tunisia respectively have a long run equilibrium with the macroeconomic variables (interest rate, exchange rate, CPI and money supply) and they would not gradually move away from each other over time.

\subsection{Granger Causality}

After proving that there is long run equilibrium between the stock market index and the four macroeconomic variables, a short run causality test can be conducted using pairwise Granger causality. Table 5 shows the results 
of the test in Egypt, the results indicate that there is a bidirectional causal relationship between exchange rate, money supply and EGX 30. There is also a causal relationship between money supply and EGX 30 running from money supply to EGX 30 and from EGX 30 to money supply. Further, the results revealed that there is a causal relationship between interest rate and EGX 30, running only in one direction from interest rate to EGX 30. As for CPI, results indicates that there is a causal relationship between CPI and EGX 30 running only from the direction of EGX 30 to CPI. However, there is evidence suggesting that there is a causal relationship between CPI and money supply running only in one direction from CPI to money supply. This indicates that there is a causal relationship running from the direction of CPI to money supply to EGX 30.

Table 5. The results of pairwise granger causality tests for Egypt

\begin{tabular}{lcc}
\hline Null Hypothesis & Prob. & Result \\
\hline LOGIR does not Granger cause LOGI & 0.0544 & Rejected \\
LOGI does not Granger cause LOGIR & 0.1074 & Accepted \\
LOGCPI does not Granger cause LOGI & 0.9054 & Accepted \\
LOGI does not Granger cause LOGCPI & 0.0207 & Rejected \\
LOGER does not Granger cause LOGI & 0.0002 & Rejected \\
LOGI does not Granger cause LOGER & 0.0346 & Rejected \\
LOGMS does not Granger cause LOGI & 0.0279 & Rejected \\
LOGI does not Granger cause LOGMS & 0.0050 & Rejected \\
LOGCPI does not Granger cause LOGMS & 0.0220 & Rejected \\
\hline
\end{tabular}

Table 6 shows the results of the causality test in Tunisia, there is a bidirectional causal relationship between interest rate and TUNINDEX. On the contrary, there was no evidence supporting that there is a causal relationship between CPI and TUNINDEX. The results also revealed that there is a causal relationship between exchange rate and TUNINDEX running only in one direction from exchange rate to TUNINDEX. Finally, the results suggested that there is a causal relationship between money supply and TUNINDEX running only from the direction of money supply to TUNINDEX.

Table 6. The results of pairwise granger causality tests for Tunisia

\begin{tabular}{lcc}
\hline Null Hypothesis & Prob. & Result \\
\hline LOGIR does not Granger cause LOGI & 0.0270 & Rejected \\
LOGI does not Granger cause LOGIR & 0.0399 & Rejected \\
LOGCPI does not Granger cause LOGI & 0.5473 & Accepted \\
LOGI does not Granger cause LOGCPI & 0.5745 & Accepted \\
LOGER does not Granger cause LOGI & 0.0436 & Rejected \\
LOGI does not Granger cause LOGER & 0.1533 & Accepted \\
LOGMS does not Granger cause LOGI & 0.0257 & Rejected \\
LOGI does not Granger cause LOGMS & 0.8384 & Accepted \\
\hline
\end{tabular}

\subsection{Co-Integrated Equation}

The second stage will show and explain the co-integrated equation or the long run equation to determine the effect of CPI, interest rate, money supply and exchange rate on the stock market index (in the long run) through the normalized co-integrating coefficients that were generated using Johansen test.

Equations 1 and 2 show the co-integrated equations for both Egypt and Tunisia, respectively.

$$
\begin{gathered}
\log I=-1.11 \log I R+1.41 \log C P I+21.15 \log E R+20.68 \log M S-0.090 @ T r e n d \\
\log I=1.15 \log I R-2.43 \log C P I+4.82 \log E R+2.07 \log M S-2.47 C
\end{gathered}
$$

Where IR is interest rate, CPI is consumer price index, ER is exchange rate and MS is the money supply.

From equation 4.1, it can be concluded that all variables are significant as they are less than the correspondent critical value five percent significance level except for interest rate, which is significant at 90 percent confidant level. The positive sign of the coefficients of CPI, exchange rate and money supply explains that they have a positive relationship with EGX 30. On the other hand, the negative sign of the coefficient of interest rate 
explains that there is a negative relationship between EGX 30 and interest rate. Further, exchange rate has the biggest coefficient followed by money supply compared to the coefficients of other variables, which means that they have a bigger effect in influencing EGX 30 than interest rate and CPI.

From equation 4.2, it can be concluded that CPI is significant at 95 percent confident level, while exchange rate is significant at 90 percent confidence level. This indicates that only the macroeconomic variables CPI and exchange rate can be significantly used to explain fluctuations in TUNINDEX in the long run. CPI has a negative coefficient while exchange rate has a positive coefficient. This indicates that there is a negative relationship between CPI and TUNINDEX and a positive relationship between exchange rate and TUNINDEX. In addition, when comparing the value of the coefficients, exchange rate has the biggest coefficient which indicates that it has a bigger impact on TUNINDEX than the other variables.

The analysis revealed that interest rate is considered an important risk factor as it affects the cost of finance and the value of the financial assets and liabilities that are being held by firms, which is the case in Egypt; however, it might not have a similar significant effect in Tunisia. When interest rate increases, people tend to shift their funds from the stock market to the bank or any other interest paid financial security, which will lead to a decrease in the stock prices. This explains the long run negative impact on the Egyptian stock market index.

As the money supply increases or the value of the local currency increases, compared to the US Dollar, people tend to invest more in the stock market as they have more money or their current income can buy more goods and services. This explains the long run positive impact on the stock market index in Egypt and in Tunisia in the case of exchange rate. Finally, when inflation increases because of an increase in demand that exceeds current supply, firms' earnings increase along with their dividends, which will make stocks more attractive and people more willing to invest in the stock market resulting in a rise in stock prices. Hence, the long run positive relationship between inflation and Egyptian stock market index. However, in Tunisia, it has the opposite effect: as inflation increases, cost of living increases and consequently this shifts funds from investment to consumption. This will decrease the trading on the stocks and this decline in the demand of the stock market will push down the value of the stocks. Hence, the long run positive relationship between inflation and the Tunisian stock market.

A well established stock market attracts foreign investments because when the market is stable to some extent, foreign investors will choose it as part of their portfolio and this will increase demand for the Egyptian pound, increase its value and attract domestic investors. On the other hand, when the stock market is declining, foreign investors will sell the stocks and leave the market, which will increase supply of the Egyptian pound and domestic investors will tend to shift their investment to an interest bearing securities, which will lead to a change in money supply and the exchange rate. Hence, the causal relationship running from stock market to exchange rate and money supply. However, the less mature the Tunisian stock market compared to the Egyptian stock market led to a causal relationship running only from exchange rate and money supply to Tunisia.

Taking that strong association into consideration, any decision made by the governments, investors and firms should not make any shocks to the economic system, the stock market or the value of the firms' stock.

\section{Conclusions}

All the macroeconomic variables used in the study namely; interest rate, exchange rate, CPI and money supply have been found to have a relationship with the stock market either a long run relationship or a causal relation in both Egypt and Tunisia. This makes it clear that there is, in fact, a relationship between stock market and these macroeconomic factors and that the macroeconomic factors play a great role in the stock market fluctuations and can be used to explain them.

According to the literature reviewed, there was a lack of studies in developing economies and there were limited studies concerning the nature of the relationship between macroeconomic variables and the stock market index in MENA region. By shedding light on this unexplored area, the results have contributed theoretically to literature. The results have proven that the relationship between macroeconomic variables and stock market differs from one economy to another even in economies with a lot of similarities. This will help investors predict the direction of the market and focus only on the significant variables and their impact on different economies. For example, knowing that money supply has a long run impact in Egypt and no significant impact in Tunisia will help give portfolio managers insights to manage their portfolio better, especially if they are diversifying the fund internationally.

Furthermore, several practical implications can be derived from these results. The macroeconomic variables such as interest rate, exchange rate, CPI and money supply have proven to be strongly associated with the stock 
market index. Government policies regarding these factors should consider this association, which will eventually lead to a more stable stock market. Moreover, investors as well as governments should take into consideration that the stock market index fluctuation has an impact on the macroeconomic variables. As indicated by the results, the stock market index in Egypt can be used to explain changes in CPI, exchange rate and money supply, while the stock market index in Tunisia can be used to explain changes in interest rate.

\section{Future Research Agenda}

The present study has further scope for more comprehensive results as several new areas for research could be derived from the results of this work. First, a further investigation can be done using the other variables that were commonly used in research to explain changes in stock prices including variables like foreign exchange reserves and oil prices which will help draw a complete picture on the factors that affect the stock market.

Second, testing the relationship between macroeconomic variables and stock market in other countries in the MENA region can also be investigated. A third area can be concerned with investigating in depth the reason behind the lack of causal relation from the stock market to some macroeconomic variables. As stated in previous research, the stock market is associated with the economic growth and it should cause changes in macroeconomic variables, but lack of this causation relationship forms a huge question mark.

Fourth, further studies can investigate the differences and similarities of the structure of the central bank and its independence, the behavior of investors and period coverage in Egypt and Tunisia and whether these changes actually affect the relationship between macroeconomic variables and the stock market.

In general, researchers found that macroeconomic variables have a strong relation with stock market, which supports the results that the four variables have some kind of association with the stock market index and the fact that there is a long run relationship between macroeconomic variables and the stock market index. This means that macroeconomic variables can be used to explain fluctuations in the Egyptian and the Tunisian stock markets indices. Any further research that helps explore this area will be of great benefit to practitioners and decision makers, especially in developing countries as they can use the research findings to enhance their economic development.

\section{References}

Abu-Libdeh, H., \& Harasheh, M. (2011). Testing for correlation and causality relationships between stock prices and macroeconomic variables: The case of Palestine securities exchange. International Review of Business Research Papers, 7(5), 141-154.

Adam, A., \& Tweneboah, G. (2008). Macroeconomic factors and stock market movement: Evidence from Ghana. http://dx.doi.org/10.2139/ssrn.1289842

Adrangi, B., Chatrath, A., \& Sanvicente, A. (2011). Inflation, output and stock prices: Evidence from Brazil. Journal of Applied Business Research (JABR), 18(1), 61-77.

Ahmed, S. (2008). Aggregate economic variables and stock market in India. International Journal of Finance \& Economics, 14, 144-164.

Ali, M. (2011). Impact of micro and macroeconomic variables on emerging stock market return: A case on Dhaka stock exchange (DSE). Interdisciplinary Journal of Research in Business, 1(5), 8-16.

Aliyu, S. (2009). Stock prices and exchange rate interactions in Nigeria: An intra-global financial crisis maiden investigation. Retrieved from http://mpra.ub.uni-muenchen.de/id/eprint/13283

Amadi, S., \& Odubo, T. (2002). Macroeconomic variables and stock prices: Causality analysis. The Nigeria J of Economic and Management Studies, 4(1\&2), 29-41.

Atje, R., \& Jovanovic, B. (1993). Stock markets development. European Economic Review, 37(2), 632-640. http://dx.doi.org/10.1016/0014-2921(93)90053-D

Bhattacharya, B., \& Mookherjee, J. (2001). Causal relationship between and exchange rate, foreign exchange reserves, value of trade balance and stock market: Case study of India. Working paper, Jadavpur University Department of Economics, Kolkata, India. Retrieved from http://www.igidr.ac.in/money/mfc_5/basabi.pdf

Bhunia, A. (2012). A causal relationship between stock indices and exchange rates-empirical evidence from India. Research Journal of Finance and Accounting, 3(1), 47-54.

Bilson, C., Brailsford, T., \& Hooper, V. (2001). Selecting macroeconomic variables as explanatory factors of emerging stock market returns. Pacific-Basin Finance Journal, 9(4), 401-426. http://dx.doi.org/10.2139/ssrn.201908 
Buyuksalvarci, A. (2010). The effects of macroeconomic variables on stock returns: Evidence from Turkey. European Journal of Social Sciences, 14(3), 404-416.

Chaudhuri, K., \& Smiles, S. (2004). Stock market and aggregate economic activity: Evidence from Australia. Applied Financial Economics, 14, 121-129. http://dx.doi.org/10.1080/0960310042000176399

Chen, N., Roll, R., \& Izedonmi, S. (1986) Economic forces and the stock market. Journal of Business, 59, 383-403. http://dx.doi.org/10.1086/296344

Coleman, A., \& Tettey, K. (2008). Impact of macroeconomic indicators on stock market performance: The case of the Ghana Stock Exchange. Journal of Risk Finance, 9(4), 365-378. http://dx.doi.org/10.1108/15265940810895025

El-Nader, H., \& Alraimony, A. (2012). The impact of macroeconomic factors on Amman stock market returns. International Journal of Economics \& Finance, 4(12), 202-213. http://dx.doi.org/10.5539/ijef.v4n12p202

Fama, E. (1981). Stock returns, real activity, inflation and money. American Economic Review, 71(4), 545-565.

Geetha, C., Mohidin, R., Chandran, V., \& Chong, V. (2011). The relationship between inflation and stock market: Evidence from Malaysia, United States and China. International Journal of Economics and Management Sciences, 1(2), 1-16.

Graham, J., \& Harvey, C. (2001). The theory and practice of corporate finance: Evidence from the field. Journal of Financial Economics, 60, 187-243. http://dx.doi.org/10.1016/S0304-405X(01)00044-7

Gunasekarage, A., Pisedtasalasai, A., \& Power, D. (2004). Macroeconomic influence on the stock market: Evidence from an emerging market in South Asia. Journal of Emerging Market Finance, 3(3), 285-304. http://dx.doi.org/10.1177/097265270400300304

Hamburger, M., \& Kochin, L. (1972). Money and stock prices: The channels of influence. Journal of Finance, 27(2), 231-249. http://dx.doi.org/10.1111/j.1540-6261.1972.tb00957.x

Hondroyiannis, G., \& Papapetrou, E. (2001) Macroeconomic influences on the stock market. Journal of Economics and Finance, 25(1), 33-49. http://dx.doi.org/10.1007/BF02759685

Horobet, A., \& Dumitrescu, S. (2009). On the causal relationships between monetary, financial and real macroeconomic variables: Evidence from central and eastern Europe. Economic Computation and Economic Cybernetics Studies and Research, 43(3), 1-17.

Ibrahim, H., \& Aziz, H. (2003). Macroeconomic variables and the Malaysian equity market: A view through $\begin{array}{llllll}\text { rolling subsamples. Journal of Economic Studies, } & 30(1), & \text { 6-27. }\end{array}$ http://dx.doi.org/10.1108/01443580310455241

Ibrahim, M. (2003). Macroeconomic forces and capital market integration: A VAR analysis for Malaysia. Journal of the Asia Pacific Economy, 8(1), 19-40. http://dx.doi.org/10.1080/1354786032000045228

Kim, K. (2003). Dollar exchange rate and stock price: Evidence from multivariate cointegration and error correction model. Review of Financial Economics, 12, 301-313. http://dx.doi.org/10.1016/S1058-3300(03)00026-0

Kraft, J., \& Kraft, A. (1977). Determinants of common stock prices: A time series analysis. Journal of Finance, 32(2), 417-425. http://dx.doi.org/10.1111/j.1540-6261.1977.tb03281.x

Kurihara, Y. (2006). The relationship between exchange rate and stock prices during the quantitative easing policy in Japan. International Journal of Business, 11(4), 375-386.

Lakshmi, K., \& Tuwajri, B. (2014). Macroeconomic forces and stock prices: Some empirical evidence from Saudi Arabia. International Journal of Financial Research, 5(1), 81-92. http://dx.doi.org/10.5430/ijfr.v5n1p81

Levine, R., \& Zervos, S. (1998). Stock markets, banks, and economic growth. American Economic Review, 88(3), 537-558.

Masuduzzaman, M. (2012). Impact of the macroeconomic variables on the stock market returns: The case of Germany and the United Kingdom. Global Journal of Management and Business Research, 12(16), 22-34.

Maysami, R., Howe, L., \& Hamzah, M. (2004). Relationship between macroeconomic variables and stock market indices: Cointegration evidence from stock exchange of Singapore's all-S sector indices. Journal Pengurusan, 24(1), 47-77. 
Mohammad, S., Hussain, A., Jalil, M., \& Ali, A. (2009). Impact of macroeconomic variables on stock prices: Empirical evidence in case of KSE (Karachi Stock Exchange). European Journal of Scientific Research, 38(1), 96-103.

Mukherjee, T., \& Naka, A. (1995). Dynamic relation between macroeconomic variables and the Japanese stock market: An application of a Vector Error Correction model. Journal of Financial Research, 18(2), 223-237. http://dx.doi.org/10.1111/j.1475-6803.1995.tb00563.x

Musílek, P. (1997). Changes in the macroeconomic variable and the stock prices. Czech Journal of Economics and Finance (Finance a uver), 47(3), 150-162.

Osamwonyi, I., \& Evbayiro-Osagie, E. (2012). The relationship between macroeconomic variables and stock market index in Nigeria. Journal of Economics, 3(1), 55-63.

Osamwonyi, I. (2003). Forecasting as a tool for securities analysis. A paper presented at a Three-day Workshop on Introduction to Securities Analysis, Organized by Securities and Exchange Commission. Lagos August 17 th.

Ozbay, E. (2009). The relationship between stock returns and macroeconomic factors: Evidence for Turkey. Devon, University of Exeter, Financial Analysis and Fund Management, Yayınlanmamı̧̧ Yüksek Lisans Tezi, Master of Science Thesis.

Pal, K., \& Mittal, R. (2011). The impact of macroeconomic indicators on Indian capital markets. Journal of Risk Finance, 12(2), 84-97. http://dx.doi.org/10.1108/15265941111112811

Pramod-Kumar, N., \& Puja, P. (2012). The impact of macroeconomic fundamentals on stock prices revisited: An evidence from Indian data. Eurasian Journal of Business and Economics, 5(10), 25-44.

Rafique, A., Amara, A., \& Sultana, N. (2014). Impact of macroeconomic variables on stock market index (a case of Pakistan). Finance Management, 57, 14099-14104.

Rapach, D., Wohar, M., \& Rangvid, J. (2005). Macro variables and international stock return predictability. International Journal of Forecasting, 21(1), 137-166. http://dx.doi.org/10.1016/j.ijforecast.2004.05.004

Ray, S. (2012). Foreign exchange reserve and its impact on stock market capitalization: Evidence from India. Research on Humanities and Social Sciences, 2(2), 46-60.

Reilly, F., \& Brown, K. (2003). Investment analysis and portfolio management (7th ed.). South-Western Cengage Learning, Mason Ohio, USA.

Singh, T., Mehta, S., \& Varsha, M. (2011). Macroeconomic factors and stock returns: Evidence from Taiwan. Journal of Economics and International Finance, 2(4), 217-227.

Sirucek, M. (2011). Effect of money supply on the Dow Jones Industrial Average stock index. Acta univ. agric. et silvic. Mendel. Brun, 60(2), 399-408. http://dx.doi.org/10.11118/actaun201260020399

Smith G. (1990). Investments, Illinois \& London: Glenview. Summers LH (1981). Inflation, the stock market, and owner occupied housing. American Economic Review, 71, 423-430.

Strong, R. (2005). Derivatives: An introduction. Thomson/South-Western Pub. Mason Ohio, USA

Talla, J. (2013). Impact of macroeconomic variables on the stock market prices of the Stockholm stock exchange (OMXS30). JÖNKÖPING UNIVERSITY: Sweden. Master of Science Thesis.

Tangjitprom, N. (2012). The review of macroeconomic factors and stock returns. International Business Research, 5(8), 107-115. http://dx.doi.org/10.5539/ibr.v5n8p107

Tsoukalas, D. (2003). Macroeconomic factors and stock prices in the emerging Cypriot equity market. Managerial Finance, 29(4), 87-92. http://dx.doi.org/10.1108/03074350310768300

Uddin, M., \& Alam, M. (2007). The impacts of interest rate on stock market: Empirical evidence from Dhaka stock exchange. South Asian Journal of Management and Sciences, 1(2), 123-132.

Ullah, F., Hussain, I., \& Rauf, A. (2014). Impacts of macroeconomy on stock market: Evidence from Pakistan. International Journal of Management and Sustainability, 3(3), 140-146.

Vejzagic, M., \& Zarafat, H. (2013). Relationship between macroeconomic variables and stock market index: Coinegration evidence from FTSE BURSA MALAYSIA HIJRAH SHARIAH INDEX. Asian Journal of Management Sciences \& Education, 2(4), 94-108.

Walter, J. (1989). Monetary aggregates: A user's guide. FRB Richmond Economic Review, 75(1), 20-28. 
Wongbangpo, P., \& Subhash, C. (2002) Stock market and macroeconomic fundamental dynamic interaction: ASEAN-5 countries. Journal of Asian Economics, 13, 27-51. http://dx.doi.org/10.1016/s1049-0078(01)00111-7

Yau, H., \& Nieh, C. (2006). Interrelationships among stock prices of Taiwan and Japan and NTD/Yen exchange rate. Journal of Asian Economics, 17, 535-552. http://dx.doi.org/10.1016/j.asieco.2006.04.006

\section{Copyrights}

Copyright for this article is retained by the author(s), with first publication rights granted to the journal.

This is an open-access article distributed under the terms and conditions of the Creative Commons Attribution license (http://creativecommons.org/licenses/by/3.0/). 